\title{
Use of Interactive Learning Media Based on Macromedia Flash on Student Learning Outcomes
}

\author{
Arjunita Eka Putri, \\ Geography Education Master Program, \\ Universitas Negeri Yogyakarta \\ Yogyakarta, Indonesia \\ arjunitaekaputri.2017@student.uny.ac.id
}

\author{
Mukminan \\ Geography Education Master Program, \\ Universitas Negeri Yogyakarta \\ Yogyakarta, Indonesia \\ mukminan@uny.ac.id
}

\begin{abstract}
The purpose of this study was to influence differences in learning outcomes between students who use macromedia flash based interactive learning media with students using conventional learning media (model/ display). This research method uses Research and Development. As the control class is class XI IPS 2 using conventional learning media (model / display), while the experimental class is class XI IPS 1 using macromedia flash-based interactive learning media, this form of learning media uses Adobe Flash CS6. There is a significant difference in the learning outcomes of the experimental class students with control class students in geography subjects at SMAN 2 Mesuji. The results of the trial exercise using macromedia flash learning media have the results of the experimental Post-test value is higher than the control class which is 83.5 the average result of the Pre-test experimental class is 73.4 and the average value of the control class Pre-test is 51.7. While the average results of the experimental Post-test value are higher than the control class, namely 83.5 for the experimental class and 68.8 for the control class.
\end{abstract}

Keywords- Interactive Learning Media, Macromedia Flash, Learning Outcomes.

\section{INTRODUCTION}

The growing world of education, the teacher in carrying out the teaching and learning process is required to use various learning strategies that enable student interaction with the teacher, students with students and students with their environment. Students are required to construct knowledge with their own abilities through activities carried out in learning activities and the material learned must be communicated. The activity process is a set of social or shared activities, educational events and directs, and is an effort to consciously or unconsciously implement the principles of education. Encouragement or motivation to carry out educational practices arises because there is an obligation to help others [6].

One of the problems experienced by teachers in learning is the lack of interest of students to read textbooks. The low reading interest can be caused by the lack of interesting teaching materials that students use, teaching materials for geography subjects, especially environmental metrics tend to still have deficiencies which include teaching material presented in student books rarely associated with actual objects or events in the real world is familiar with students, student books only teach theories, the images are less interesting because they are still black and white, the absence of multimedia-based geography teaching materials, even if they have not been utilized optimally and monotonous media make students bored so they need the existence of alternative media that can increase students' reading interest in learning [1, 14].

Multimedia learning is a tool or intermediary that can be used to channel various messages (knowledge, skills, and attitudes) and can stimulate thoughts, feelings, attention, and learning abilities so that the learning process intentionally occurs, aims and is controlled. Multimedia learning is very useful to facilitate students in learning so that the learning process is more interactive, effective, and interesting to please so that the quality of student learning increases. The development of learning media is very appropriate because with a learning system that involves various media (multimedia) such as text, images, audio, video, animation, digital e-books in learning, teachers can present subject matter that is more interesting, not monotonous and facilitate delivery to learners[2, 3, 4, 15].

According to De Pietro, There are numerous factors to consider when deciding to use learning: (1) Devices and technologies that are available for use in instruction, (2) Students' aptitude for using devices, (3) Students' inclination to engage with content presented on new media devices, (4) The format of the course material [5]. Does the course material exist in a digital format that can be presented on a device, or does the material need to be converted to a digital format? There could be significant cost and time associated with converting materials into interactive or multimedia pieces. Interactivity and the need for learners to make inferences is often not as effective as direct instruction in promoting meaningful learning [9]. Although the term interactive means different things to different people in different contexts [10], in the context of this review we define interactivity as a characteristic of learning environments that enable multidirectional communication [8]. Underlying interactivity is the idea of a two-way action (between and instructor) as opposed to a one-way action (i.e., from instructor to learner). However, we further 
qualify our definition of interactivity by clarifying that the goal of the participants' actions needs to be to foster learning, that is, to help the learner change his or her knowledge consistent with the instructional goal [20]. In this regard, navigation alone, for example, would not be enough to make a learning environment interactive, unless navigating the environment can lead directly to the construction of knowledge or meaningful learning $[11,12,13]$.

For example, an alternative to presenting a multimedia explanation to teach photosynthesis may consist of asking students to engage in mixedinitiative problem solving with a pedagogical agent [7]. One of the animation media that can be used as learning media is macromedia flash-based animation media in the form of Software in the form of Adobe Flash CS6 in order to find solutions to improve student learning outcomes, because it has several advantages that can display / explain one material or sub-material by combining text, images, audio, animation or video. So, students will be more interested and avoid boredom. Adobe flash provides computer software that is used to create animation, vector and bitmap image videos and interactive multimedia [3]. Adobe Flash CS6 has many functions, such as to create object animated films, create presentations, ad animation, and games. According to Westriningsih, the latest features in Adobe Flash CS6, namely: provide support for HTML 5.0; export of symbols and animation sequences that quickly produce sprite sheets to enhance the gamming, workflow, and performance experience; provide support for Android and iOS with the latest Adobe Flash Player; its performance provides loading of large photos to be faster. this was realized thanks to the Adobe Mercury graphics engine that was able to minimize rendering time [21].

\section{RESEARCH METHODS}

This study uses Research and Development. Research and Development methods are used to produce certain products and test the effectiveness of these products. The development model used by researchers is the Hannafin and Peck development model that is oriented towards products in the form of learning media such as learning videos or learning multimedia [16].

According to Tegeh, the Hannafin and Peck development model consists of 3 phases in development research namely Phase Analysis (analyze), Design Phase (design) and Development (implementation) with the aim of making learning media for material living environment. The subject of this research was the eleventh-grade high school students [18]. Social studies at Mesuji 2 State Senior High School, with a total of 41 people and the research location is in the village of Makarti Mulya, Mesuji Subdistrict, OKI District, SUMSEL Province. The development procedure in this study is a procedure that is in accordance with the Hannafin and Peck development [18], then continued with formative evaluation Tessmer [19] with the aim of comparing learning media in improving student learning outcomes in subject's geography.

Data collection techniques used in this study are test questions. The test questions have been tested for validity and reliability before the test questions are tested to students. Data analysis techniques used in this study with descriptive quantitative data analysis techniques using questionnaire sheets and test data analysis conducted by comparing the average increase in results obtained by students at the pre-test and posttest in the control class and in the class experiment by using an average score (mean).

\section{RESULTS AND DISCUSSION}

The results of the study were obtained from the research instruments used, namely test questions. The research instrument was given twice, at the time of the pre-test and post-test. The complete data of the research results are as follows [17]:

A. Pre-Test and Post-Test Control Class Scores

Data summary of the pre-test and post-test values for the control class can be seen in table 1 .

TABLE I. FREQUENCY DISTRIBUTION OF THE PRETEST AND POST-TEST VALUES OF THE CONTROL CLASS

\begin{tabular}{|c|c|c|c|}
\hline \multicolumn{2}{|c|}{ Pre-Test } & \multicolumn{2}{c|}{ Post-Test } \\
\hline Interval Score & F & Interval Score & F \\
\hline $40-43$ & 10 & $60-65$ & 9 \\
\hline $44-47$ & 6 & $66-71$ & 5 \\
\hline $48-51$ & 4 & $72-76$ & 9 \\
\hline $52-55$ & 6 & $77-80$ & 14 \\
\hline $56-60$ & 15 & $81-85$ & 4 \\
\hline Total & $\mathbf{4 1}$ & Total & $\mathbf{4 1}$ \\
\hline
\end{tabular}

From table 1 data, the frequency of the most pre-test scores of the control class is at intervals of 56-60 totaling 15 people and the frequency of the post-test scores of the most control classes is at 7780 intervals totaling 14 people.

\section{B. Pre-Test Value and Post-Test Experiment Class}

Data summary of the pre-test and post-test values for the experimental class can be seen in table 2 .

TABLE II. FREQUENCY DISTRIBUTION OF THE PRETEST AND POST-TEST VALUES OF THE EXPERIMENTAL

\begin{tabular}{|c|c|c|l|}
\hline \multicolumn{2}{|c|}{ Pre-Test } & \multicolumn{1}{|c|}{ Post-Test } \\
\hline Interval Score & F & Interval Score & F \\
\hline $55-60$ & 5 & $70-75$ & 9 \\
\hline $61-64$ & 6 & $76-80$ & 7 \\
\hline $65-70$ & 11 & $81-85$ & 14 \\
\hline $71-74$ & 9 & $86-90$ & 5 \\
\hline $75-80$ & 10 & $91-95$ & 6 \\
\hline Total & $\mathbf{4 1}$ & Total & $\mathbf{4 1}$ \\
\hline
\end{tabular}


From table 2 data the frequency of the most pretest values of the experimental class is at intervals of $65-70$, totaling 11 people and the pre-test scores of the most control classes are at intervals of $81-85$, totaling 14 people.

Based on the descriptive data above, the average result of the Pre-test experimental class is higher than the average value of the Pre-test control class, namely the average value of the Pre-test experimental class of 73.4 and the average value of the Pre-test of the control class. amounting to 51.7. While the average results of the experimental Post-test value are higher than the control class, namely 83.5 for the experimental class and 68.8 for the control class.

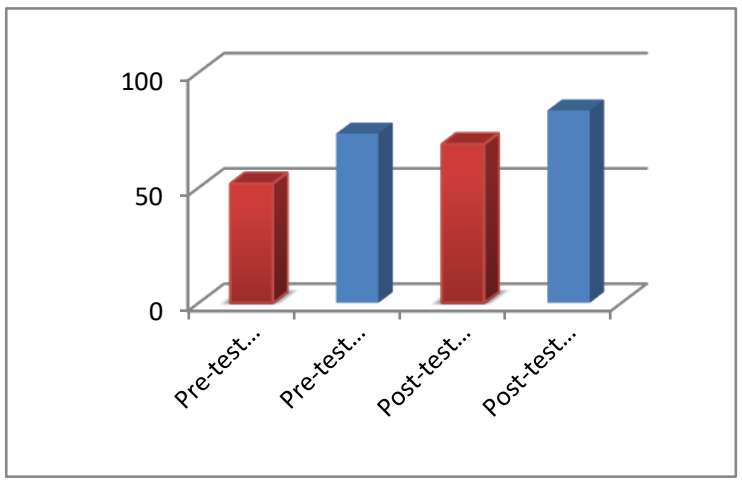

Figure 1. Average Pre-Test and Post-Test Trunk Diagrams

\section{IV.DISCUSSION}

Based on descriptive statistical analysis that is comparing the average value between the control class and the experimental class. The average value of the Pre-test experimental class is 73.4 and the average control class Pre-test value is 51.7. While the average results of the experimental Post-test value are higher than the control class, namely 83.5 for the experimental class and 68.8 for the control class. The average Post-test value is a significant difference after being given Adobe Flash Cs6-based learning media. Therefore, it can be concluded that the geography learning media influences the learning outcomes obtained by students.

\section{CONCLUSION}

Based on the results of research and discussion, it can be concluded that there are differences in student learning outcomes using Adobe Flash Cs6-based learning media and students who use conventional learning media (model), so that the use of learning media can influence student learning outcomes.

\section{REFERENCE}

[1] Allesi \& Trolliph, Chart of Learner Characteristics, 2000. Retrieved http://www.uiowa.edu/ c07w180e/current/Fig132_Learners.pdf. Retrieved 10 July 2018.

[2] Arsyad, A. Instructional Media. Jakarta: PT Rajagrafindo Persada, 2011.
[3] Darmawan, D. Educational Innovation: Approach to Multimedia Technology and Online Learning Practices. Bandung: PT Remaja Rosdakarya, 2014.

[4] Daryanto. Learning Media: Its Role Is Very Important in Achieving Learning Objectives. Yogyakarta: Gava Media, 2010.

[5] DePietro, Peter. Tool Literacy. Transforming Education with New Media: Participatory, 2013.

[6] Pedagogy, Interactive Learning, and Web 2.0. pp. 15-25. Published by: Peter Lang AG. Stable URL: https://www.jstor.org/stable/42982120.

[7] Djamarah, S.B and Zain, A. Teaching and Learning Strategies. Jakarta: Rineka Cipta, 2013.

[8] Lester, J. C., Stone, B. A., \& Stelling, J. D. Lifelike pedagogical agents for mixed problem solving in constructivist learning environments. User Modeling and User-Adapted Interaction, 9, 1999, pp. 1-44.

[9] Markus, M. L. Toward a "critical mass" theory of interactive media. In J. Fulk \& C.Steinfeld (Eds.). Organization and Communication Technology, Newbury Park, CA: Sage, 1990, pp. 194-218.

[10] Mayer, R. E. Should there be a three-strikes rule against pure discovery learning? American Psychologist, 59, 2004, pp. 1419.

[11] McMillan, S. J. Exploring models of interactivity from multiple traditions: user, documents, and systems. In L. Lievrouw, \& S. Livingston (Eds), Handbook of New Media. London: Sage, 2002, pp. 1-19.

[12] Puntambekar, S., Stylianou, A., \& Hübscher, R. Improving navigation and learning in hypertext environments with navigable concept maps. Human Computer Interaction, 18, 2003, pp. 395-428.

[13] Rouet, J. The skills of document use. Mahwah, NJ: Erlbaum, 2006.

[14] Rouet, J., \& Potelle, H. Navigational principles in multimedia learning. In R. Mayer (Ed). Cambridge handbook of multimedia learning New York: Cambridge University Press, 2005, pp. 297-312.

[15] Sadulloh, U. Introduction to Educational Philosophy. Bandung: Alfabeta, 2004.

[16] Sanaky, H. A. Interactive-Innovative Learning Media. Yogyakarta: Kaukaba Dipantara, 2015.

[17] Sugiyono. Educational Research Methods. Bandung: Alfabeta, 2012.

[18] Sugiyono. Statistics for Research. Bandung: Alfabeta, 2012.

[19] Tegeh, Jamel \& Pudjawan. Development Research Model. Yogyakarta: Graha Ilmu, 2014.

[20] Tessmer, M. Planning and Conducting Formative Evaluation. London: Kogan Page Limited, 1998.

[21] Wagner, E. D. In support of a functional definition of interaction. The American Journal of Distance Education. 8, 1994, pp. 6-29.

[22] Westriningsih. Adobe Flash CS6. Yogyakarta: Andi Yogyakarta, 2012. 